\title{
Article \\ A Germline-Encoded Structural Arginine Trap Underlies the Anti-DNA Reactivity of a Murine V Gene Segment
}

\author{
Ronny Petterson dos Santos Araújo ${ }^{1}$, Renato Kaylan Alves França ${ }^{1}$, Napoleão Fonseca Valadares ${ }^{1}{ }^{10}$, \\ Andrea Queiroz Maranhão 1,2 (D) and Marcelo Macedo Brigido 1,2,*(D) \\ 1 Department of Cellular Biology, Institute of Biology, University of Brasilia, Brasilia 70910-900, Brazil; \\ ronnypetter@hotmail.com (R.P.d.S.A.); renatokaylan@gmail.com (R.K.A.F.); napo@unb.br (N.F.V.); \\ andreaqm@unb.br (A.Q.M.) \\ 2 Instituto Nacional de Ciência e Tecnologia (iii-INCT), São Paulo 05403-000, Brazil \\ * Correspondence: brigido@unb.br
}

\section{check for}

updates

Citation: dos Santos Araújo, R.P.; França, R.K.A.; Valadares, N.F.;

Maranhão, A.Q.; Brigido, M.M. A

Germline-Encoded Structural

Arginine Trap Underlies the

Anti-DNA Reactivity of a Murine V Gene Segment. Int. J. Mol. Sci. 2021, 22, 4541. https://doi.org/ 10.3390/ ijms22094541

Academic Editor:

Marcos Lopez-Hoyos

Received: 21 February 2021

Accepted: 15 April 2021

Published: 26 April 2021

Publisher's Note: MDPI stays neutral with regard to jurisdictional claims in published maps and institutional affiliations.

Copyright: (c) 2021 by the authors. Licensee MDPI, Basel, Switzerland. This article is an open access article distributed under the terms and conditions of the Creative Commons Attribution (CC BY) license (https:/ / creativecommons.org/licenses/by/ $4.0 /)$.

\begin{abstract}
Autoimmunity may have its origins of early repertoire selection in developmental B cells. Such a primary repertoire is probably shaped by selecting B cells that can efficiently perform productive signaling, stimulated by self-antigens in the bone marrow, such as DNA. In support of that idea, we previously found a $\mathrm{V}$ segment from $\mathrm{V}_{\mathrm{H}} 10$ family that can form antibodies that bind to DNA independent of CDR3 usage. In this paper we designed four antibody fragments in a novel single-chain pre-BCR (scpre-BCR) format containing germinal $\mathrm{V}$ gene segments from families known to bind DNA $\left(\mathrm{V}_{\mathrm{H}} 10\right)$ or not $\left(\mathrm{V}_{\mathrm{H}} 4\right)$ connected to a murine surrogate light chain (SLC), lacking the highly charged unique region (UR), by a hydrophilic peptide linker. We also tested the influence of CDR2 on DNA reactivity by shuffling the CDR2 loop. The scpre-BCRs were expressed in bacteria. $\mathrm{V}_{\mathrm{H}} 10$ bearing scpre-BCR could bind DNA, while scpre-BCR carrying the $\mathrm{V}_{\mathrm{H}} 4$ segment did not. The CDR2 loop shuffling hampered $\mathrm{V}_{\mathrm{H}} 10$ reactivity while displaying a gain-of-function in the nonbinding $\mathrm{V}_{\mathrm{H}} 4$ germline. We modeled the binding sites demonstrating the conservation of a positivity charged pocket in the $\mathrm{V}_{\mathrm{H}} 10 \mathrm{CDR} 2$ as the possible cross-reactive structural element. We presented evidence of DNA reactivity hardwired in a V gene, suggesting a structural mechanism for innate autoreactivity. Therefore, while autoreactivity to DNA can lead to autoimmunity, efficiently signaling for B cell development is likely a trade-off mechanism leading to the selection of potentially autoreactive repertoires.
\end{abstract}

Keywords: V genes; anti-DNA; pre-BCR; autoreactivity; B cell's repertoire

\section{Introduction}

Self-antigens are known for their participation in the development and progress of autoimmune diseases such as systemic lupus erythematosus (SLE) [1], rheumatoid arthritis [2] and type 1 diabetes [3] among others. However, the presence of circulating self-antigens itself cannot be attributed to the development of autoimmunity. Several mechanisms act to minimize the effects of potentially autoreactive immune cells through negative selection [4], receptor editing [5] and anergy [6].

Autoreactivity in the immunological system can be observed from the early stages of B cell development. In fact, the majority of the repertoires in the early stages of B cells are potentially autoreactive $[7,8]$. B-cells precursors are generated in the bone marrow $(\mathrm{BM})$ and necessitate a constant and weak survival signaling to differentiate into circulating B-cells. The constant signaling is mostly originated in the pre-B cell receptor (pre-BCR) expressed on the surface of pre-B cells, ensuring proliferation and survival signals in the bone marrow [9]. Hence, DNA reactive pre-BCRs may benefit from circulating DNA fragments for survival [10].

The pre-BCR contains a rearranged heavy variable domain $\left(\mathrm{V}_{\mathrm{H}}\right)$ along with a mouse isotype heavy chain, the $\mu \mathrm{HC}$. The $\mathrm{V}_{\mathrm{H}}$ is unique for each clone of pre-B cell clone and is 
formed in a random rearrangement process that connects three gene segments: variable heavy $\left(\mathrm{V}_{\mathrm{H}}\right)$, $\mathrm{D}$, and joining heavy $\left(\mathrm{J}_{\mathrm{H}}\right)$, while the $\mathrm{V}_{\mathrm{H}}$ codes for the CDR1 and 2, $\mathrm{D}$, and $\mathrm{J}_{\mathrm{H}}$ codes for $\mathrm{CDR} 3$, the most variable of the three complementarity determining regions (CDR) [11]. The $\mu \mathrm{HC}$ pairs to the surrogate light chain (SLC) to assemble the pre-BCR. The SLC seems to be an important component for signaling generation interacting with self-antigens through the highly charged unique regions (URs), or with the stromal cells from the bone marrow. The URs are non-Ig domains of the two noncovalent bonded polypeptides, VpreB and $\lambda 5$, which constitute the SLC [12-14]. The SLC is only expressed in a limited temporal stage of $\mathrm{B}$ cell development and may be involved in $\mathrm{IgH}$ allelic exclusion [15], downregulation of recombinant mechanisms [16], and functionally testing the $\mu \mathrm{H}$ chain, consequently shaping $\mathrm{IgH}$ repertoire [17].

The emergence of the rearranged light chain $\left(\mathrm{V}_{\mathrm{L}}\right)$ substituting the SLC drives the appearance of the membrane-associated B-cell receptor (BCR). During this developmental stage, the signaling of the newly formed immature B-cell relies on antigenic stimulus for survival and selection [18]. At this point, BCR auto and polyreactivity help to delineate the primary repertoire [19], and polyreactive $\mathrm{V}$ gene have been shown to be associated with immunological protection [20]. Nevertheless, the origin and molecular mechanisms involved in autoreactivity and the correlation among individual $\mathrm{V}$ genes and self-antigen recognition is still an incomplete scenario.

We previously reported that antibodies harboring a $V$ gene $\left(V_{H}\right)$ of the mouse $V_{H} 10$ family of heavy chain variable gene segments, bind DNA in a disproportional frequency compared to other heavy $\mathrm{V}$ gene families [21]. Indeed, recombinant antibodies coded by $\mathrm{V}_{\mathrm{H}} 10$ germline sequences are less dependent on CDR3 to develop anti-DNA binding activity, suggesting that the encoded germline $\mathrm{V}_{\mathrm{H}} 10$ segment itself contains structural elements that facilitate the creation of an anti-DNA paratope [21]. Germline V genes encoded DNA reactivity could help explain the observed part of the B-cell primary repertoire autoreactivity. However, it is unknown if the germline-encoded $V_{H} 10$ gene segment is sufficient to encompass a DNA binding site as an innate (germline) property. If it does, this property should be already in any $\mathrm{V}_{\mathrm{H}} 10$ encoded pre-BCR. To test this hypothesis, we constructed a recombinant mouse pre-BCR containing different $\mathrm{V}_{\mathrm{H}}$ segments and tested DNA binding in vitro. Additionally, we investigated structural features in the $V_{H} 10$ germline sequence and located its DNA binding capacity to CDR2.

\section{Results}

\subsection{Assembling a Recombinant scpre-BCR for Testing $V_{H}$ Intrinsic Binding}

To test the germline $\mathrm{V}_{\mathrm{H}} 10$ gene fragments' intrinsic DNA binding, we designed novel scpre-BCR molecules containing a murine germline $\mathrm{V}_{\mathrm{H}}$ gene fragment in a pre-BCR context. The recombinant single-chain pre-BCR (scpre-BCR) contained a heavy chain composed of a germline $\mathrm{V}_{\mathrm{H}} 10$, a synthetic CDR3, and a germline FW4. This $\mathrm{V}_{\mathrm{H}}$ domain combination was based on a previous anti-DNA scFv [21] and was fused through a 15-mer linker to a recombinant fusion of mouse VpreB and $\lambda 5$, as the J donor (Figure 1). This mouse synthetic VpreBJ construct was based on a human construct from a previous work [22], replacing the human sequences for its mouse homolog for VpreB and $\lambda 5$ (Supplementary Figure S1). The UR sequences (highly charged unique regions) were removed to reduce nonspecific binding. The loop at the junction of VpreB and $\lambda 5$ was preserved as described [22].

As a control, three other scpre-BCRs were constructed; the first with a germline $V_{H} 4$ family gene fragment, and two others with an artificial sequence derived from the germline $\mathrm{V}_{\mathrm{H}} 10$ gene fragment containing the $\mathrm{V}_{\mathrm{H}} 4$ germline CDR2, and vice-versa (Figure 1). Sequences and alignment are shown in Supplementary Materials. The single-chain constructs also harbored a protein $\mathrm{A}$ tag used for affinity purification and immune detection. These recombinant scpre-BCR molecules had molecular weight varying between 36 and $37 \mathrm{kDa}$ and were used to test binding to DNA. 


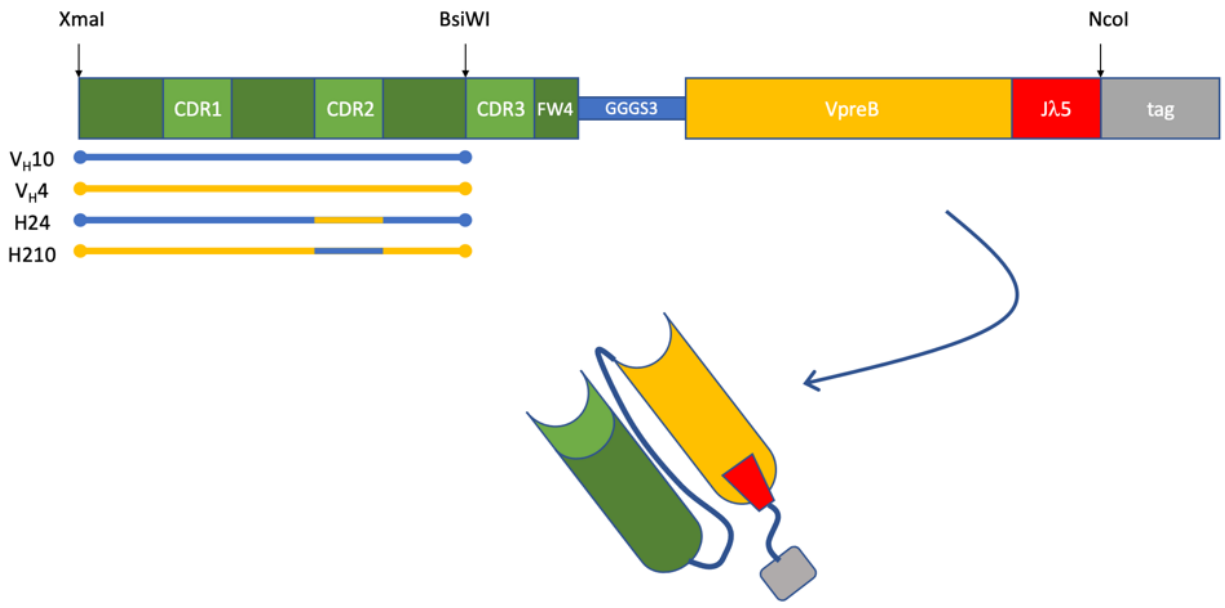

Figure 1. Schematic representation of recombinant scpre-BCR constructs. Selected V genes were put together with a common HCDR3/FW4. A $V_{L}$-like domain was assembled with the mouse VpreB sequence and the $\lambda 5$ region that functions as an FW4 segment in the native VpreB $/ \lambda 5$ complex. These two variable domains were connected by a (GGGGS) 3 linker to form a single-chain immunoglobulin pre-BCR domain. Four constructs of these murine scpre-BCR were used in this work, varying their $\mathrm{V}_{\mathrm{H}}$ counterparts: germinal $\mathrm{V}_{\mathrm{H}} 10$ or $\mathrm{V}_{\mathrm{H}} 4$, and these germinal $\mathrm{V}$ segments harboring CDR2 from the other.

\subsection{Production and Molecular Characterization of the Recombinant scpre-BCRs}

The scpre-BCRs were expressed in sHuffle LysY E. coli cells by induction with IPTG at $22{ }^{\circ} \mathrm{C}$. Intracellular soluble fractions were obtained by sonication and affinity purified using rabbit IgG Sepharose column, based on their protein A tag. Eluted fractions were visualized in SDS-PAGE (Figure 2A) and confirmed by Western blot (Figure 2B), Proteins with $37 \mathrm{kDa}$ were dominant on those fractions and correctly immune detected.

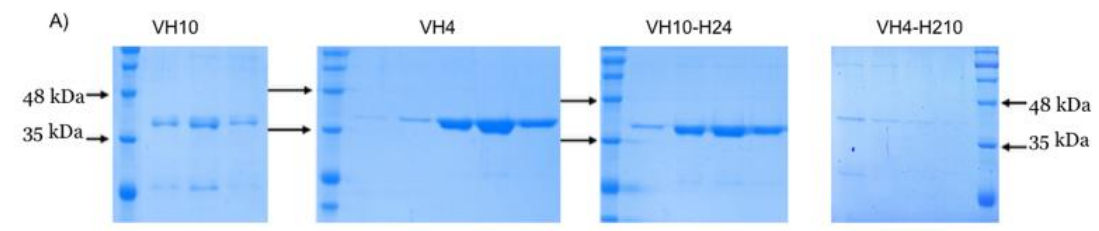

B)

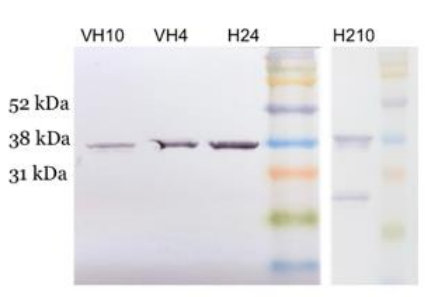

C)

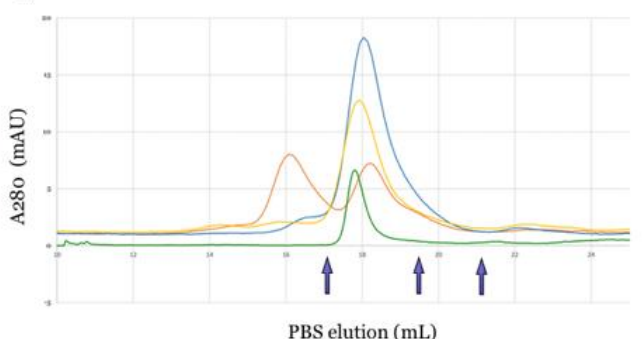

Figure 2. scpre-BCR purification and characterization. (A) scpre-BCR $\mathrm{V}_{\mathrm{H}} 10, \mathrm{~V}_{\mathrm{H}} 4, \mathrm{~V}_{\mathrm{H}} 10-\mathrm{H} 24$ and $\mathrm{V}_{\mathrm{H}} 4-\mathrm{H} 210$ and were produced and fractions obtained from IgG Sepharose affinity purification were analyzed by SDS-PAGE. (B) Purified scpre-BCR were analyzed by Western blot. The recombinant proteins were detected by their protein A tag using alkaline phosphatase conjugated rabbit IgG. (C) The recombinant proteins samples were also analyzed by size exclusion chromatography (in blue scpre-BCR- $\mathrm{V}_{\mathrm{H}} 10$; in yellow scpre-BCR- $\mathrm{V}_{\mathrm{H}} 10-\mathrm{H} 24$; in green scpre-BCR- $\mathrm{V}_{\mathrm{H}} 4-\mathrm{H} 210$ and in orange scpre-BCR- $\mathrm{V}_{\mathrm{H}}$ 4). Standards molecular markers are indicated by arrows (left to right: $76 \mathrm{kDa}, 29 \mathrm{kDa}$ and $13.7 \mathrm{kDa}$ ). 
The purified proteins were concentrated and analyzed by SEC. SEC profile data showed that scpre-BCR $\mathrm{V}_{\mathrm{H}} 10, \mathrm{~V}_{\mathrm{H}} 4-\mathrm{H} 210$ and $\mathrm{V}_{\mathrm{H}} 10-\mathrm{H} 24$ presented a single peak profile suggesting that these recombinant scpre-BCRs appears as monomers. In contrast, scpre-BCR $\mathrm{V}_{\mathrm{H}} 4$ showed a different profile, with two peaks, indicating that monomeric and dimeric (or an extended monomer) conformations were present for this construct (Figure 2C).

\subsection{The Germline scpre-BCR- $V_{H} 10$ Binds $D N A$}

We tested the binding capacity of the four recombinant scpre-BCRs against different forms of DNA molecules through direct ELISA assay. The scpre-BCR containing the germline VH10 gene segment bound more than the other construction to either native or denatured DNA, while the $\mathrm{VH} 4$ containing scpreBCR was the worst DNA binder (Figure 3). Interestingly, the exchanged CDR2 scpreBCR- $\mathrm{V}_{\mathrm{H}} 10-\mathrm{H} 24$ did not show binding activity against the DNA antigens tested, but the scpreBCR- $\mathrm{V}_{\mathrm{H}} 4-\mathrm{H} 210$, which contains the $\mathrm{V}_{\mathrm{H}} 10$ CDR2 showed an improved binding comparing to scpreBCR- $\mathrm{V}_{\mathrm{H}} 4$.

A)

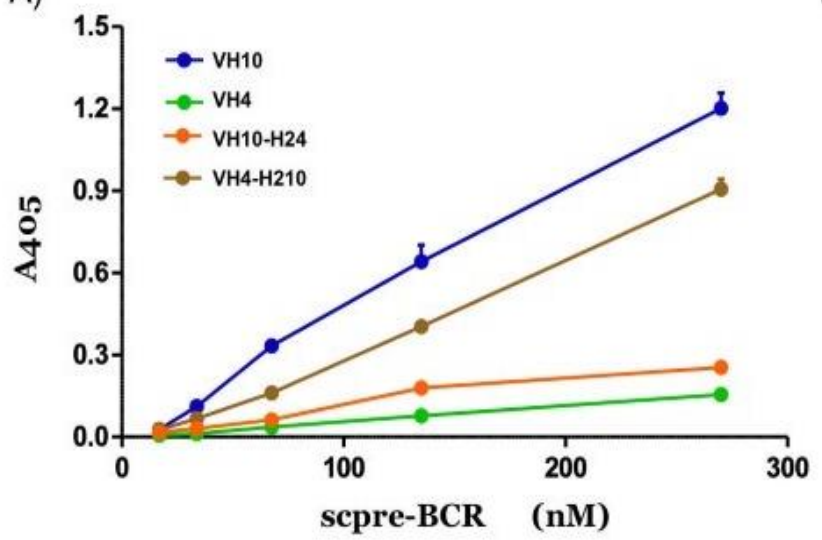

B)

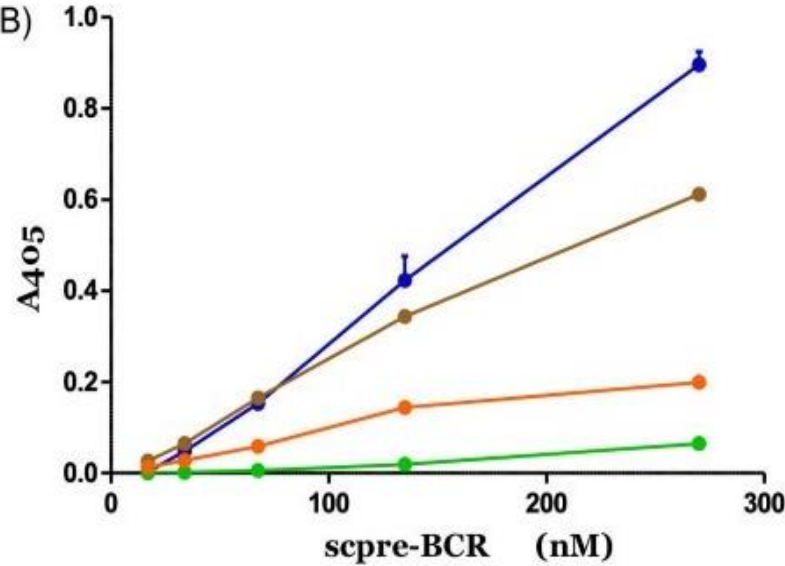

Figure 3. DNA binding activity of scpre-BCRs. The scpre-BCRs were assayed for DNA binding activity by ELISA immunoassay. Plates were coated with either ssDNA (A) or dsDNA (B), and binding activity of recombinant scpre-BCRs were tested. $\mathrm{V}_{\mathrm{H}} 10$ (blue), $\mathrm{V}_{\mathrm{H}} 4$ (green), $\mathrm{V}_{\mathrm{H}} 4$ germline harboring $\mathrm{V}_{\mathrm{H}} 10 \mathrm{CDR} 2$ (brown), and $\mathrm{V}_{\mathrm{H}} 10$ germline with CDR2 of $\mathrm{V}_{\mathrm{H}} 4$ (orange) were assayed. Triplicates are shown as mean \pm SEM with absorbance at $405 \mathrm{~nm}$ plotted against scpre-BCR concentration.

\section{4. $V_{H} 10$ Germline Sequences Contain DNA Binding Residues in CDR2}

To address the structural role of the $\mathrm{V}$ gene segment in the binding of DNA we searched the PDB for $\mathrm{V}_{\mathrm{H}} 10$ containing antibodies. Eight unique entries that used $\mathrm{V}_{\mathrm{H}} 10$ germlines sequences were identified (PDB codes: 4Z8F, 1CBV, 2HKF, 3CXD, 3I2C, 3SGD, $4 \mathrm{QNP}, 4 \mathrm{QWW}$ ). Two of them were anti-DNA antibodies (4Z8F and 1CBV). Except for 4ZF8, which appears in the germline configuration, all other $\mathrm{V}_{\mathrm{H}}$ showed hypermutations leading to residue changes (from two to 11 residues). The structural alignment of the $\mathrm{V}_{\mathrm{H}} 10$ antibodies revealsed a strong superposition (Figure 4) with a reduced RMSD (Supplementary Figure S1). These structures superposed well to each other, and since each antibody had a unique CDR3 loop size and sequence, this region presented higher alignment divergence. The CDR2 was positioned on the side of the molecule revealing a projection of exposed hydrophilic amino acid residues. 


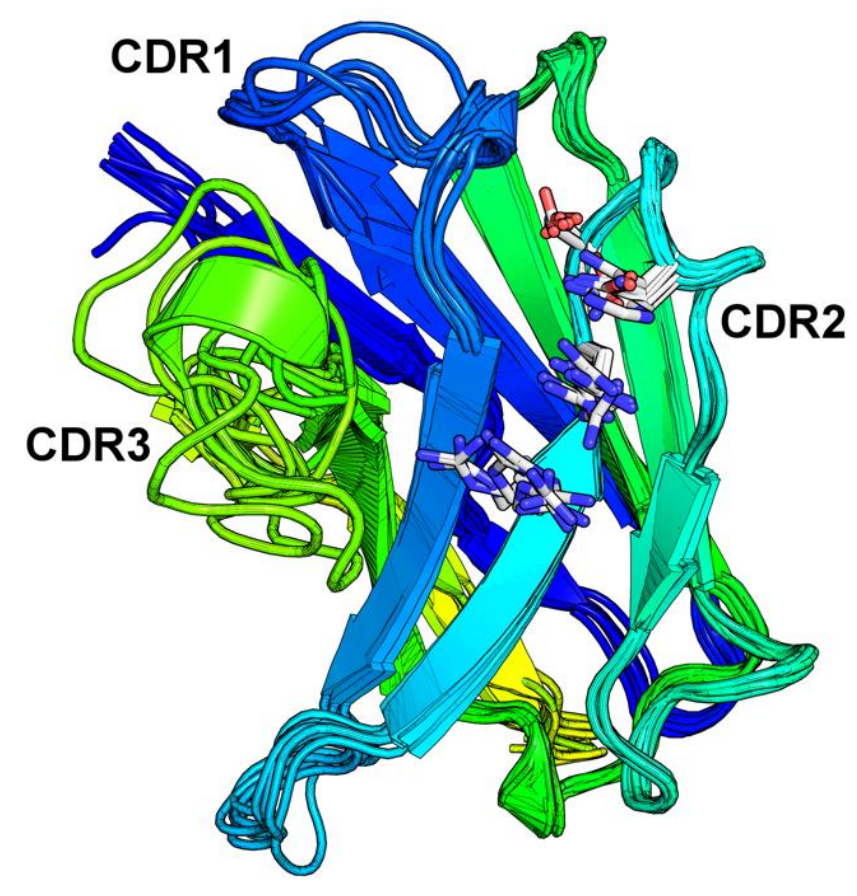

Figure 4. VH10 derived antibodies present the conserved residues Arg50, Arg52, Ser52a and Asn53 which contribute to their anti-DNA reactivity. Superposition of the VH chains of crystal structures of VH10 derived antibodies, PDB codes 4Z8F, 1CBV, 4QWW, 2HKF, 3CXD, 3I2C, 3SGD and 4QNP. The CDR1, CDR2 and CDR3 regions are labeled. The conserved residues Arg50, Arg52, Ser52c and Asn56 are represented as sticks, as is His56 in PDB 3I2C. Numbering follows Kabat convention.

The two anti-DNA antibodies bind DNA using heavy chain's CDR1, 2, and 3. The 1 CBV(BV 04-01) structure has low resolution, whereas the 1.75 A resolution 4Z8F (S1-S15) crystal structure is more reliable, as indicated by the 99th and 96th percentiles in the clashscore and MolProbity scores, respectively [23]. In the former complex a trinucleotide lies along a groove and contacts all three CDRs, while in the second, two oligonucleotides bind simultaneously and shared DNA binding residues in CDR1, 2, and 3 with 1CBV. Since two oligonucleotides molecules bind to $4 \mathrm{Z} 8 \mathrm{~F}$, for practical reasons, we may define the paratope as having two binding pockets, one for each oligonucleotide; the first one involving CDR1 and CDR2 contacts and the second involving CDR1 and CDR3 contacts.

In both models, CDR2 seems to contribute with the same germline-encoded residues. Two Arginine residues (50 and 52), in the base of the CDR2, are involved in binding to DNA (Figure 5). In $4 \mathrm{Z} 8 \mathrm{~F}$, the $\mathrm{Arg}^{50}$ amino group makes a hydrogen bond to phosphate 1 oxygen. In $1 \mathrm{CBV}$ this same residue is in Van der Waals (VdW) contact with the sugar backbone. 4Z8F makes two additional hydrogen bonds: $\mathrm{Arg}^{52}$ makes a hydrogen bond to another oxygen of the same phosphate group and $\mathrm{Asn}^{53}$ makes a hydrogen bond to the first ribose $\left(\mathrm{O}^{\prime}\right)$. The residue Ser ${ }^{52 a}$ makes a hydrogen bond to the first phosphate group of the trinucleotide in $1 \mathrm{CBV}$. In $4 \mathrm{Z} 8 \mathrm{~F}$ Ser ${ }^{52 \mathrm{c}}$ makes a hydrogen bond to the same $\mathrm{O}$ atom. Taken together these five residues, $\mathrm{Arg}^{50}, \mathrm{Arg}^{52}, \mathrm{Asn}^{53}$ and either $\mathrm{Ser}^{52 \mathrm{a}}$ or Ser ${ }^{52 \mathrm{c}}$, are in close contact to antigen in both complexes, making either hydrogen bonds or $\mathrm{VdW}$ contacts. Distances to antigen among these residues range from 2.84 to $4.0 \AA$.

It is interesting to observe that these residues are also involved in complex formation in $\mathrm{V}_{\mathrm{H}} 10$ containing antipeptide antibodies (2HKF, 3CXD, and 4QWW). All four residues are involved in hydrogen bonds to the antigen, except for 4QWW model. In the CDR2 of 4 QWW, Ser ${ }^{52 a}$ makes no contact but $\mathrm{Asn}^{53}$ is in VdW contact (3.87 $\AA$ ) with the acetylcholinesterase antigen. The model $4 \mathrm{QNP}$, also a $\mathrm{V}_{\mathrm{H}} 10$ antibody, is not symmetrical, and the two Fab binds antigens differently. In this model, the CDR2 residue $\left(\mathrm{Ser}^{52 \mathrm{c}}\right)$ is the only heavy chain involved in binding to antigen, though the model was not further analyzed. Interestingly, in the 2HFK model that includes water molecules, the four residues con- 
tact antigen by direct hydrogen bonds and indirect bonds through four water molecules, suggesting a complex interaction network that traps two carboxyl groups.
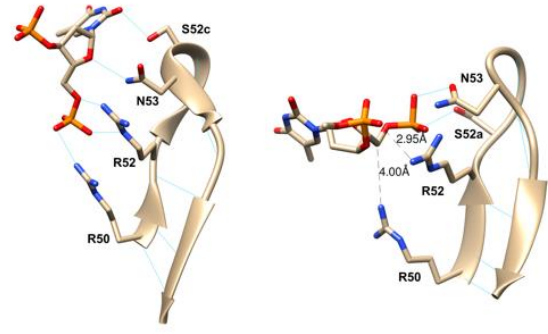

$1 \mathrm{CBV}$

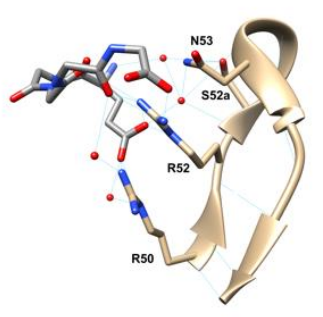

4QWW

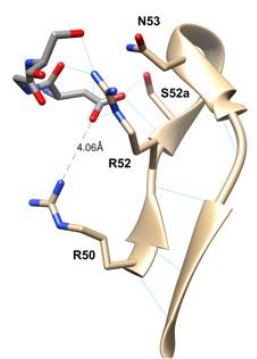

$2 \mathrm{HKF}$

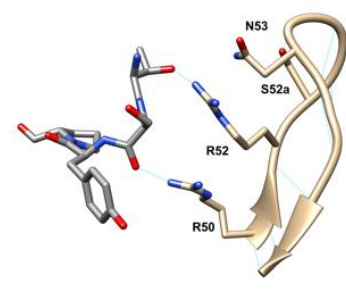

3CXD

Figure 5. Comparison of antigens contacts in the CDR2 of $\mathrm{V}_{\mathrm{H}} 10$ containing antibodies. The CDR2 of 4Z8F, 1CBV, 4QWW, 2HKF, and 3CXD, from residue 50 to 58 are depicted. Contact residues Arg50, Arg52, Ser52a (or Ser52c for 4Z8F) and Asn53 is shown with side chain and labelled. Water residues (red spheres) are included in the 4QWW model. Antigens contact residues are also in evidence: oligo-dT for the first two and peptide for the others.

Sequence alignment of the $\mathrm{V}_{\mathrm{H}} 10$ chain used in scpre-BCR with the two anti-DNA antibodies 1CBV [24], 4Z8F [25] shows that the $\mathrm{V}$ chain sequences are very similar and share the adjacent arginine residue at position 50 and 52 (Figure 6).Thus, a potential salt-bridge could be formed with DNA's phosphate groups, allowing the $V_{H} 10$ germline chain the ability to bind DNA independently of CDR3 or the $\mathrm{V}_{\mathrm{L}}$ domain.

10

20

30

40

50

60

$\ldots|\ldots| \ldots|\ldots| \ldots|\ldots| \ldots|\ldots| \ldots|\ldots| \ldots|\ldots| \ldots$. $\ldots$. $\ldots|\ldots| \ldots|\ldots|$

scpre-BCR-VH10

BV04-01

S1-S5

EVOLVES GGGLVOPKGSLKLSCAASGFTFNTYAMA WVROAPGKGLEWVA RIRSKSSNYATYYADSVKD EVQPVETGGGLVQPKGSLKLSCAASGFSFNTNAMNWVRQAPGKGLEWVARIRSKSNNYATYYADSVKD EVQLVESGGGLVQPKGSLKLSCAASGFTENPYAMNWVRQAPGKGLEWVARIRSKSNNYATYYADSVKD

CDR1

CDR2

70

80

90

100

110

$\ldots|\ldots| \ldots|\ldots| \ldots b c \ldots|\ldots| \ldots|\ldots| \ldots|a b c d e f g h \ldots| \ldots|$.$| .$

scpre-BCR-VH10 RFTISRDDSQSMLYLQMNNLKTEDTAMYYCVREFQOARSL-----DY WGQGTLVTV

BV0 4-01

S1-S5 RFTISRDDSQSMLYLQMNNLKTEDTAMYYCVRERGAPLYYGNGAWFAYWGQGTLVTV

\section{CDR3}

Figure 6. Sequence alignment of $\mathrm{V}_{\mathrm{H}}$ domain of scpre-BCR- $\mathrm{V}_{\mathrm{H}} 10$ and two anti-DNA antibodies. CDR residues are boxed. Residue numbering and CDR's follow Kabat definition.

\subsection{A Structural Model of scpreBCR- $V_{H} 10$ Supports DNA Intrinsic Binding for DNA}

We developed structural models to assess the potential sites for DNA binding in the scpreBCR- $\mathrm{V}_{\mathrm{H}} 10$. Homology modeling was performed based on the $4 \mathrm{Z} 8 \mathrm{~F}$ structure. Ten best structures were considered for analyses. All models showed a single-chain conventional $\mathrm{V}_{\mathrm{H}}-\mathrm{V}_{\mathrm{L}}$ pairing. Compared to another pre-BCR structure in PDB (2H32), it showed a similar conformation of the VpreB domain and the J-like strand. The 2H32 structure contained the UR sequences that were exchanged in the VpreBJ synthetic domain for an artificial loop. Nevertheless, in both models, this region preserved the immunoglobulin fold occupying the center of the immunoglobulin barrel in the proximity to the heavy chain CDR3.

Interestingly, the model scpreBCR- $\mathrm{V}_{\mathrm{H}} 10$ complexed with a single oligonucleotide suggesting that the VpreBJ domain does not contribute for binding with the antigen (Supplementary Table S1). However, the $\mathrm{V}_{\mathrm{H}}$ domain showed many contacts and H-bonds, as also observed in the $4 \mathrm{Z} 8 \mathrm{~F}$ template. The CDR3 residue $\mathrm{Glu}^{95}$ seemed to contributes to the binding pocket, appearing beneath the antigen binding pocket (Figure 7). 

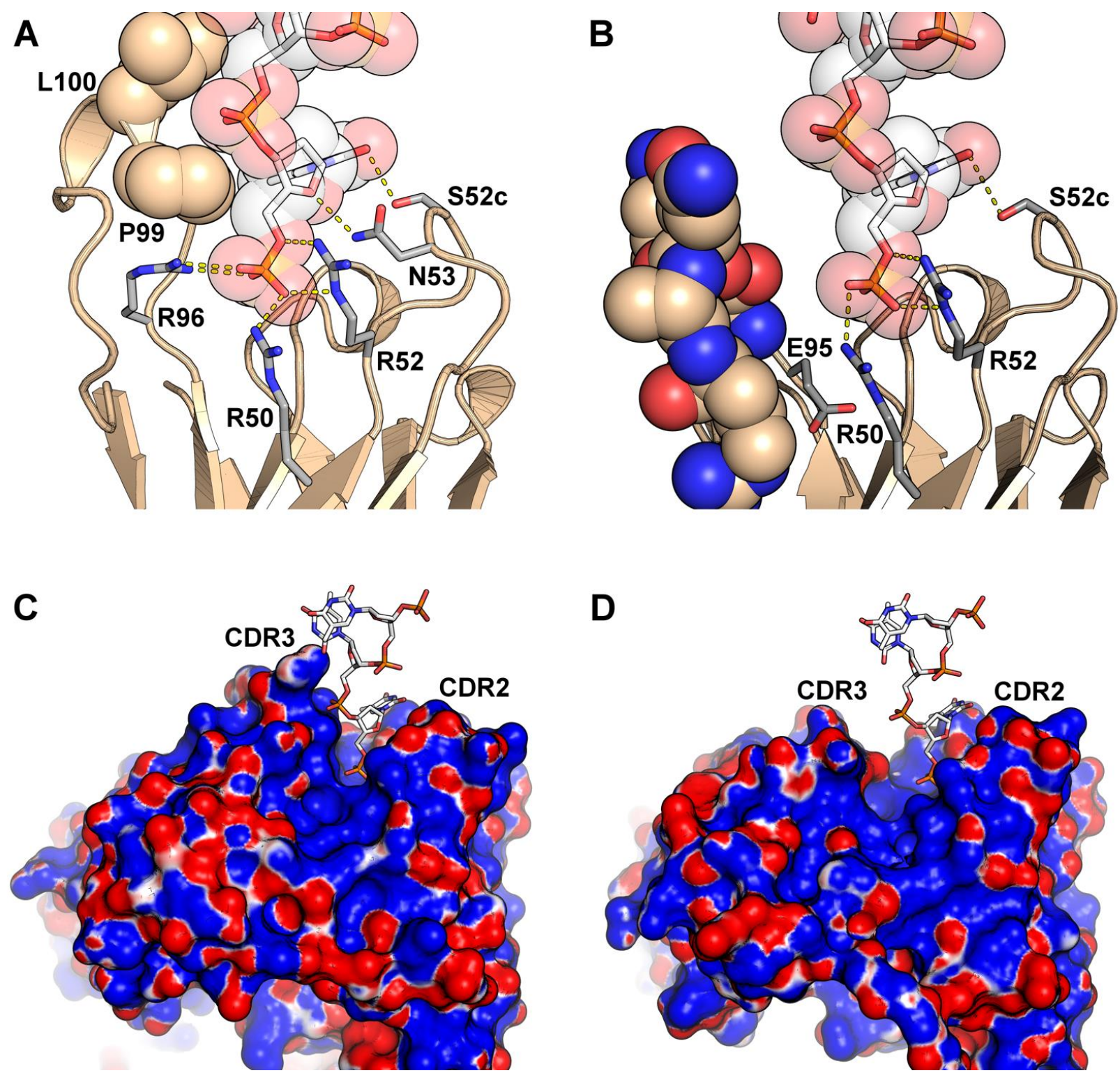

Figure 7. Interactions between anti-DNA antibodies and deoxythymidine oligonucleotides. (A) Interactions of labeled residues in both CDR2 (R50, R52, N53 and S52c) and CDR3 (R96, P99 and L100) contribute to deoxythymidine oligonucleotide binding in the crystal structure of the VH10 containing antibody 4Z8F. (B) Model of scpre-BCR-VH10 interacting with a deoxythymidine oligonucleotide. The labeled residues R50, R52 and S52c from CDR2 participate in the oligonucleotide binding, while residues from the CDR3 (represented as solid spheres) do not. The CDR3 residue E95 that appears close to R50 is also in evidence. (C) Surface electrostatic potential for antibody $4 \mathrm{Z} 8 \mathrm{~F}$ with the deoxythymidine oligonucleotide represented as sticks. (D) Surface electrostatic potential the model of scpre-BCR-VH10 with the deoxythymidine oligonucleotide represented as sticks. In both $(\mathbf{C}, \mathbf{D})$ the CDR2 and CDR3 regions are labeled, and the electrostatic potential was calculated from $-3 \mathrm{kT} / \mathrm{e}$ to $+3 \mathrm{kT} / \mathrm{e}$ using APBS, and colored with a gradient from red (negative) to blue (positive).

The majority of CDR2 residues involved in interactions with DNA and peptide antigens (Figure 5) were also observed in the model scpre-BCR. Arg ${ }^{50}$ and $\mathrm{Arg}^{52}$ and $\operatorname{Ser}^{52 \mathrm{c}}$ appeared in contact in all models making hydrogen bonds and possibly salt bridges (Supplementary Table S1 and Figure S2). These residues shaped a binding pocket with arginine residues at the bottom. Consequently, the model's electrostatic surface presented a positively charged path in the CDR2 starting on the paratope floor, running up the CDR2 loop. A comparison of the antibody-DNA complex between $4 \mathrm{Z} 8 \mathrm{~F}$ and the model scpre-BCR showed that CDR2 dominate the binding in the model scpre-BCR (Figure 7). 


\section{Discussion}

We had previously reported that $\mathrm{V}_{\mathrm{H}} 10$ family germline members have an intrinsic preference for DNA binding [21]. Thus, the $\mathrm{V}$ gene segment seems to have a major role in this specific binding independent of the CDR3. In this work, we developed an experimental system based on a single-chain molecule to access a germline $V_{\mathrm{H}} 10$ gene segment's binding activity as part of a fully reconstitute paratope in a pre-BCR setup. To accomplish this, we needed to consider that the $V_{H}$ gene fragment was only part of the $V_{H}$ domain, which also included a CDR3 and an FW4. Even though the V gene is deterministic to antigen binding [26], it is generally recognized that the heavy chain CDR3 is the most influential region for antigen binding [27]. Thus, we attempted to minimize the CDR3 impact on binding by choosing a sequence that did not favor or hamper DNA binding. We used a synthetic CDR3 previously shown to be neutral for DNA binding, not affecting selection in a phagedisplay experimental approach, thus mitigating its impact on the recombinant pre-BCR.

To build the recombinant pre-BCR, we chose to assemble it as single-chain antibody fragments. Hence, the $V_{H}$ domain was connected through a flexible linker to a VpreB/ $/ \lambda 5$ fusion (VpreBJ) domain as a substitute light chain. We constructed a mouse VpreBJ domain based on a human single-domain VpreBJ [22], avoiding the non-immunoglobulin sequences (URs) that project outside of the Ig domain in a tail-like structure. We opted not to include those regions, as they do not contribute to the Ig domain assembly and could bias the binding activity.

Our work focused on the construction of pre-BCR based on the scFv format, a singlechained molecule that emulates a pre-BCR paratope. Antibody fragments such as $\mathrm{scFv}$ have been used to investigate the binding properties of several Ig variable domains. The advantage comes from easier and inexpensive expression that can be made in bacterial systems, such as recombinant $E$. coli strains, maintaining antigen-binding properties comparable to the whole molecule [28]. We showed that the scpre-BCR could be purified in soluble form from E. coli extracts, using a conventional expression protocol and purification. Interestingly, the scpre-BCR using $\mathrm{V}_{\mathrm{H}} 4$ appeared with two hydrodynamic forms, suggesting that a fraction of it could appear as dimers, or even in an extended state. However, all the other constructions behaved similarly in SEC, compatible with monomer conformation.

The data on the production of scpre-BCR suggest it is an efficient and straightforward $\mathrm{scFv}$-like system for expression and studying individual $\mathrm{V}_{\mathrm{H}}$ properties. It could also be useful to express antibody fragments that are hard to produce and which binding is dominated by the heavy chain. A similar expression system based on Fab-like pre-BCR was proposed before [29], but here the design was more compact and single-chained, simplifying production and manipulation. Thus, this new kind of molecule is a new acquisition to the toolkit for antibody engineering.

The DNA binding analysis showed that scpre-BCR- $\mathrm{V}_{\mathrm{H}} 10$ bound to different DNA molecule types, in contrast with scpre-BCR- $\mathrm{V}_{\mathrm{H}} 4$ that did not show significant binding activity. However, the insertion of the $\mathrm{V}_{\mathrm{H}} 10 \mathrm{CDR} 2$ loop (as in scpre-BCR- $\mathrm{V}_{\mathrm{H}} 4-\mathrm{H} 210$ ) allowed the $\mathrm{V}_{\mathrm{H}} 4$ germline sequence to bind DNA. Moreover, scpre-BCR- $\mathrm{V}_{\mathrm{H}} 10-\mathrm{H} 24$, which contains the CDR2 loop derived from the germline $\mathrm{VH} 4$, did not show significant binding activity. Thus, the presence of the $\mathrm{V}_{\mathrm{H}} 10 \mathrm{CDR} 2$ loop seems to be critical for DNA binding in this experimental setup, corroborating the role for the CDR2 in $V_{H} 10$ germline sequences. The importance of heavy chain CDR2 in antigen binding has been reported before [25,30].

Our working hypothesis is that the germline $\mathrm{V}_{\mathrm{H}} 10$ gene segment has an intrinsic reactivity to DNA. Therefore, $\mathrm{V}_{\mathrm{H}} 10$ containing antibodies should naturally bind DNA, at least in the initial stages of its ontogeny and, consequently in a $\mathrm{V}_{\mathrm{H}} 10$ containing pre-BCR. Our recombinant soluble pre-BCR bound DNA dependent on the presence of a $\mathrm{V}_{\mathrm{H}} 10$ germline, and especially in the CDR2 shuffled constructs. Taken together, these data suggest a mechanistic role for the germline CDR2 in DNA binding. The participation of CDR2 arginine residues in DNA binding has been reported before [31,32]. Moreover, the structural analysis of the $\mathrm{V}_{\mathrm{H}} 10$-containing antibodies revealed spatial conservation of the CDR2 loop that included a path of hydropathic amino acid residues, with a marked positive 
charge due to two adjacent arginine residues. In histones, arginine-rich DNA binding proteins, these residues were shown to directly interact with backbone phosphate forming hydrogen bonds and salt bridges [33]. Moreover, clustered arginines were previously implicated in tight binding to phosphate groups [34]. This germline arginine-positive charged path, which appears clearly in the molecular model of the scpre-BCR, suggests a docking pocket, a trap for nucleic acid and other negatively charged molecules.

A dilemma for this hypothesis is that all $\mathrm{V}_{\mathrm{H}} 10$ containing antibodies would naturally be an autoantibody, due to their intrinsic reactivity to autoantigens. Indeed, among $\mathrm{V}_{\mathrm{H}} 10$ sequences in the antibodies database, a large portion are anti-DNA, but not all [21]. Among those not annotated as anti-DNA, there should be a number that are cross-reactive to DNA or other nucleic acid-containing compounds. A clear exact example of this is $4 \mathrm{Z} 8 \mathrm{~F}$ (mentioned before), an antibacterial lipid A that was later found to be cross-reactive to DNA [25]. Other antibodies could also present, at various degrees, with such a property. Furthermore, $\mathrm{V}_{\mathrm{H}} 10$ antibodies could lose or reduce such an intrinsic property after a negative influence of the rearranged CDR3 [35], or after pairing with an appropriate light chain $[30,36]$. Additionally, the affinity maturation process may change directly the self-reactive $\mathrm{V}$ gene [37].

The data presented here suggest that a germline $V_{H} 10$ chain possessed an intrinsic reactivity for DNA. Even though we did not quantitate this affinity, we showed binding to both ss and ds-DNA in the context of an artificial pre-BCR. Furthermore, we also implicate the CDR2 in this autoreactivity. The $\mathrm{V}_{\mathrm{H}} 10$ gene family is poorly used in mouse antibodies, a possible consequence of its autoreactivity. It would be expected that germinalencoded autoreactivity is deleterious, and eventually eliminated over evolutive time. Autoreactivity seems to be a positively selected trait, and represents a major driver for the $\mathrm{B}$ cell repertoire $[19,38,39]$. Moreover, some $\mathrm{V}$ genes are associated with reactivity to commensal microbiota components, such as phospholipid [26], which may be protective to pathobionts [20] and affect the mature B cell repertoire [40,41]. The cross-reactivity shown for the $\mathrm{V}_{\mathrm{H}} 10$ antibody $4 \mathrm{Z} 8 \mathrm{~F}$ to the phosphate moiety of bacterial Lipid-A [25] suggests that, for $\mathrm{V}_{\mathrm{H}} 10$ antibodies, DNA reactivity brings a premade binding site for other anionic molecules. Therefore, maintaining germline hardwired reactivity for such common antigens seems beneficial, warranting a quick start to immunity in developing animals.

In summary, our results corroborate the hypothesis that a specific murine $\mathrm{V}$ gene family can generate anti-DNA antibodies in a pre-BCR context. For that, we developed a novel antibody fragment (scpre-BCR) to test individual $\mathrm{V}$ genes. We corroborated the $\mathrm{V}_{\mathrm{H}} 10$ gene segment germline contribution and implicated CDR2 for DNA binding through gain and loss-of function constructs in this scpre-BCR model. Hence, VH10 germline CDR2 codes for a structural arginine trap, suggesting that DNA reactivity can be hard-wired in the germline repertoire.

\section{Materials and Methods}

\section{1. scpre-BCR Gene Design}

Four single-chain pre-BCR gene fragments were designed using germline $\mathrm{V}_{\mathrm{H}}$ sequences and a mouse surrogate light chain (SLC) engineered based on the previously proposed single domain VpreBJ design concept [22]. Their single domain SLC contained a VpreB sequence fused to a J-like segment of $\lambda 5$ gene to complete a variable-like VpreBJ domain. The mouse single domain SLC was designed to substitute the human sequences for their mice homologs. The sequences for the murine VpreB region (X05556) and the J region from $\lambda 5$ (AJ852426) were obtained at the Uniprot database (http:/ / www.uniprot.org accessed on 5 February 2014) (Supplementary Figure S3).

The heavy chain domains were derived from murine germinal sequences of $V_{H} 10$ (IGHV10-3*01) and $\mathrm{V}_{\mathrm{H}} 4$ (IGHV4-1*02) families. A third $\mathrm{V}_{\mathrm{H}}$ domain sequence $\mathrm{V}_{\mathrm{H}} 10-\mathrm{H} 24$ was built replacing the CDR2 loop (residues 50-58) of the germline $V_{H} 10$ for the corresponding sequence in the CDR2 of $\mathrm{V}_{\mathrm{H}} 4$ germline (Kabat numbering and CDR definition). The forth $\mathrm{V}_{\mathrm{H}}$ construction, named $\mathrm{V}_{\mathrm{H}} 4-\mathrm{H} 210$, was assembled using the $\mathrm{V}_{\mathrm{H}} 4$ 
germline inserted with the corresponding $\mathrm{V}_{\mathrm{H}} 10$ CDR2 loop sequence (residues 50-58) (Supplementary Figure $\mathrm{S} 2$ ). All $\mathrm{V}_{\mathrm{H}}$ gene segments were fused to a common CDR3 and FRW4 based on the mouse $\mathrm{J}_{\mathrm{H}} 4$ [21]. The CDR3 was chosen not to impact binding to DNA. Thus, a single hydrophilic sequence (EFQQARSLDY) was chosen derived from the phagedisplay selection on oligo $\mathrm{dT}$, that showed a neutral enrichment (selected/unselected $\sim 1$ ) either in the $\mathrm{V}_{\mathrm{H}} 10$ or $\mathrm{V}_{\mathrm{H}} 4$ libraries [21]. The single-chain pre-BCR fragment (scpre-BCR) contained one $\mathrm{V}_{\mathrm{H}}$ and the $\mathrm{VpreBJ}$ domains linked by a linker peptide of 15 amino acids residues $(\mathrm{GGGGS})_{3}$.

\section{2. scpre-BCR Expression Vectors}

The scpre-BCR ORF was designed based on Escherichia coli highly expressed preferential codons using the Backtranseq program from the EMBOSS package [42]. The coding sequences were chemically synthesized. The scpre-BCR synthetic gene was cloned in the pIg16 expression vector [43] along with a Protein A tag. Initially, the scpre-BCR- $\mathrm{V}_{\mathrm{H}} 10$ plasmid and pIg16 vector was digested with restriction enzymes Xma I and Nco I (New England Biolabs, Ipswich, MA, USA) overnight at $37^{\circ} \mathrm{C}$. Insert and vector were ligated with T4 DNA ligase (Merck, Darmstadt, Germany) incubated overnight at $4{ }^{\circ} \mathrm{C}$, and the transformation was performed by electroporation (Gene Pulser Xcell ${ }^{\mathrm{TM}}$ Electroporation System Bio-Rad) using XL1 blue E. coli strain. Electroporated samples were cultivated in LB agar plates with $150 \mu \mathrm{g} / \mathrm{mL}$ ampicillin for selection at $37^{\circ} \mathrm{C}$ overnight. A recombinant pIg16 vector harboring scpre-BCR- $\mathrm{V}_{\mathrm{H}} 10$ was used for subsequent cloning of $\mathrm{V}_{\mathrm{H}} 4$, $\mathrm{V}_{\mathrm{H}} 10-\mathrm{H} 24$ and $\mathrm{V}_{\mathrm{H}} 4-\mathrm{H} 210$ inserts using Xma I (New England Biolabs, Ipswich, MA, USA) and BsiWI (Thermo Fisher Scientific, Waltham, MA, USA) restriction enzymes following manufacturers' instructions. Recombinant plasmids were checked by Sanger sequencing.

\subsection{Recombinant Antibody Expression}

High-quality Qiagen prepared plasmids were used to transform SHuffle ${ }^{\circledR}$ T7 Express pLys $Y$ Competent $E$. coli by heat shock. Transformants were plated in LB agar medium with $150 \mu \mathrm{g} / \mathrm{mL}$ ampicillin and $10 \mu \mathrm{g} / \mathrm{mL}$ chloramphenicol. A preselection step was performed to optimize recombinant protein expression. About twenty random transformant colonies were picked to LB agar medium plates supplemented with $150 \mu \mathrm{g} / \mathrm{mL}$ ampicillin in the presence of either $1 \%$ glucose or $1 \mathrm{mM} \mathrm{IPTG}$ (isopropyl $\beta$-d-1-thiogalactopyranoside, Merck, Darmstadt, Germany). After at least $9 \mathrm{~h}$ of incubation at $37^{\circ} \mathrm{C}$ colonies that showed a slower growth on IPTG plates compared to that observed on glucose plates were selected for expression. Individual clones were picked and incubated in $5 \mathrm{~mL}$ of LB broth supplemented with ampicillin $150 \mu \mathrm{g} / \mathrm{mL}$ overnight at $37^{\circ} \mathrm{C}$ and $250 \mathrm{rpm}$. The following day, $2 \mathrm{~mL}$ of the overnight cultivated sample was inoculated in $200 \mathrm{~mL} \mathrm{LB}$ supplemented with $150 \mu \mathrm{g} / \mathrm{mL}$ ampicillin and incubated at $37^{\circ} \mathrm{C}$, and $250 \mathrm{rpm}$ until an OD of $0.8-1.0$ was attained. Cultures were induced with $0.5 \mathrm{mM}$ IPTG overnight at $22^{\circ} \mathrm{C}$ and $250 \mathrm{rpm}$. After induction, cells were centrifuged at $7500 \mathrm{rpm}$ for $10 \mathrm{~min}$ and the pellets were stored at $-20^{\circ} \mathrm{C}$ until use. Recombinant protein production was checked by SDS-PAGE and Western blot (WB). For SDS-PAGE, BLUeye Prestained Protein Ladder (Merk, Darmstadt, Germany) was used, and for the WB assay, we used an Amersham ${ }^{\mathrm{TM}} \operatorname{Protran}^{\circledR} 0.2 \mu \mathrm{m}$ nitrocellulose membrane and Amersham ${ }^{\mathrm{TM}} \mathrm{ECL}^{\mathrm{TM}}$ Rainbow $^{\mathrm{TM}}$ Marker Full Range (Merck, Darmstadt, Germany). After protein transfer, recombinant proteins were probed with a rabbit IgG conjugated with alkaline-phosphatese (AP) (Thermo Fisher Scientific, Waltham, MA, USA).

\subsection{Recombinant Protein Purification}

Pellets from induced cells were resuspended in $15 \mathrm{~mL}$ of lysis buffer $(75 \mathrm{mM}$ Tris, $300 \mathrm{mM} \mathrm{NaCl}$ ) and lysed by sonication (Q700/QSonica, Newtown, CT, USA) on ice. Sonication was performed in cycles of $10 \mathrm{~s}$ followed by $1 \mathrm{~min}$ and $40 \mathrm{~s}$ of cooling for 30 cycles (5 min under sonication). The resulting sample was centrifuged at $8000 \mathrm{rpm}$ for $30 \mathrm{~min}$. The soluble fractions were diluted 1:1 in binding buffer solution (10 mM Sodium Phosphate, $500 \mathrm{mM} \mathrm{NaCl}$ ), filtered using a $0.22 \mu \mathrm{m}$ filter, and transferred to a $50 \mathrm{~mL}$ superloop (Cytiva, 
Marlborough, MA, USA). Recombinant pre-BCRs were purified by affinity chromatography using a Rabbit IgG-agarose resin (Thermo Fisher Scientific, Waltham, MA, USA). The process was carried out in AKTA Pure System (Cytiva, Marlborough, MA, USA). Binding and elution ( $0.1 \mathrm{M}$ Glycine, $0.15 \mathrm{M} \mathrm{NaCl}, \mathrm{pH} 2.4)$ steps were executed following the manufacturers' guidelines. The fractions were concentrated using $3 \mathrm{kDa}$ Amicon centrifugal filter (Merck, Darmstadt, Germany) and quantified by absorbance (Shimadzu UV1800, Kyoto, Japan).

Selected protein fractions and standards (conalbumin $76 \mathrm{kDa}$, carbonic anhydrase $29 \mathrm{kDa}$ and ribonuclease A $13.7 \mathrm{kDa}$ ) were diluted in PBS and analyzed by size exclusion chromatography (SEC). One $\mathrm{mL}$ of each sample was injected in a Superdex ${ }^{\mathrm{TM}} 200$ 10/300 GL column (Cytiva, Marlborough, MA, USA) connected to an AKTA Pure System employing a $1 \mathrm{~mL} / \mathrm{min}$ flow rate.

\subsection{DNA Binding Assay}

The scpre-BCRs were tested on their abilities to bind DNA. Calf thymus DNA (Thermo Fisher Scientific, Waltham, MA, USA) was used to prepare samples of dsDNA $(20 \mu \mathrm{g} / \mathrm{mL})$ and ssDNA $(20 \mu \mathrm{g} / \mathrm{mL})$ to coat the ELISA plates (Nunc, Maxisorp 96 well, Thermo Fisher Scientific, Waltham, MA, USA). The ssDNA from calf thymus was obtained through boiling for $20 \mathrm{~min}$ and then promptly transferring it to ice immediately before its use for coating the plate. Before coating, the plates for ds and ssDNA assay were irradiated with UV light for 25 min to optimize DNA adsorption to the plate. Coating of ds and ssDNA were performed overnight at $4{ }^{\circ} \mathrm{C}$. A serial dilution (dilution ratio 1:1) of the scpre-BCRs on the coated plates was conducted using an initial concentration of $10 \mu \mathrm{g} / \mathrm{mL}$ with resulting concentrations of $5,2.5,1.25$, and $0.625 \mu \mathrm{g} / \mathrm{mL}$. The amount of protein added was normalized by scanning densitometry of SDS-PAGE samples. The concentration of each sample was normalized considering the area of the most abundant, expected sized, band. To detect the binding activity the protein A tag was probed with rabbit IgG conjugated with alkaline phosphatase (AP) (Thermo Fisher Scientific, Waltham, MA, USA). p-NitroPhenyl-Phosphate (PNPP) was used as chromogenic substrate at $1 \mathrm{mg} / \mathrm{mL}$ (Thermo Fisher Scientific, Waltham, MA, USA). The assays were performed in triplicates. All incubation steps lasted for $1 \mathrm{~h}$ with $3 \times$ PBST washes between them.

\subsection{Structural Evaluation of $V_{H} 10$ Antibodies}

The structure of $\mathrm{V}_{\mathrm{H}} 10$ containing antibodies was accessed from the Protein Data Bank (www.rcsb.org accessed on 1 May 2020) after their identification using the Blast program at NCBI (blast.ncbi.nlm.nih.gov accessed on 30 April 2020). The mouse germline $\mathrm{V}_{\mathrm{H}} 10$ sequence (IGHV10-3*01) was blasted to the PDB dataset. The best scoring heavy chain was checked for germline identification using IgBlast (https:/ / www.ncbi.nlm.nih.gov/igblast/ accessed on 15 May 2020). We considered for analyses the best scoring PDB entries identified by IgBlast as composed by a mouse $V_{H} 10$ germline sequence. Structures were analyzed using Chimera [44]. Distances, contacts, and hydrogen bonds were retrieved with Cocomaps [45]. Structural superposition and graphics were generated with Chimera. The numbering followed Kabat's definition and was assigned using Abnum (http:/ / www. bioinf.org.uk/abs/abnum/ accessed on 19 January 2021).

\subsection{Modeling of the scpre-BCR-V $V_{H} 10$}

The deposited sequence, structure model and electron density map coefficients of the antigen-binding fragments of the S1-15 anti-lipid A monoclonal antibody in complex with a DNA oligonucleotide 5P-TTTTT-3P were retrieved from the Protein Data Bank (PDB code 4Z8F). The structure model and electron density were analyzed using the program COOT [46]. The water molecules were removed from the crystallographic model, and this model was used as a template in the subsequent molecular modelling steps. The sequence of the scpre- $\mathrm{BCR}-\mathrm{V}_{\mathrm{H}} 10$ was manually aligned to the $4 \mathrm{Z} 8 \mathrm{~F}$ sequence. The program MODELLER 9.24 [47] was employed to generate several comparative molecular 
models of the scpre-BCR- $\mathrm{V}_{\mathrm{H}} 10$. The stereochemistry of the models was evaluated using the Molprobity server [23].

The I-TASSER server [48] was also employed to produce homology models of the scpre-BCR- $\mathrm{V}_{\mathrm{H}}$ 10. I-TASSER modeling was guided by tailored restraints based on the $4 \mathrm{Z} 8 \mathrm{~F}$ deposited crystal structure. Additionally, I-TASSER used LOMETS to identify several deposited crystal structures that were used as threading templates. The quality of each model was accessed by the C-score and the RMSD values.

Supplementary Materials: The following are available online at https:/ /www.mdpi.com/article/10 .3390/ijms22094541/s1, Figure S1: Scheme of scpre-BCR recombinant protein, Figure S2: Alignment of recombinant $\mathrm{V}_{\mathrm{H}}$ gene segment produced as scpre-BCR, Figure S3: Structural alignment of eight VH10 containing PDB models, Table S1: WdV contacts and H-Bonds in model scpre-BCR-VH10.

Author Contributions: Conceptualization and experiment design, A.Q.M. and M.M.B.; experimental investigation, R.P.d.S.A. and R.K.A.F.; protein models construction and analyses M.M.B. and N.F.V.; supervision, M.M.B.; project administration, M.M.B.; writing—original draft preparation, R.P.d.S.A., N.F.V. and M.M.B.; writing—review and editing, A.Q.M. and M.M.B.; funding acquisition, A.Q.M. and M.M.B. All authors have read and agreed to the published version of the manuscript.

Funding: This research was funded by CAPES (Coordination for the Improvement of Higher Education Personnel) and CNPq (National Research Council) that granted student scholarships, and research reagents and material were funded by FAP-DF (Research Foundation of Federal District).

Institutional Review Board Statement: Not Applicable.

Informed Consent Statement: Not applicable.

Acknowledgments: We thank Connie McManus for English revision of the manuscript.

Conflicts of Interest: The authors declare no conflict of interest.

\begin{tabular}{|c|c|}
\hline $\mathrm{AP}$ & Alkaline Phosphatase \\
\hline BCR & B Cell Receptor \\
\hline BM & Bone marrow \\
\hline CDR & Complementarity Determining Region \\
\hline dsDNA & Double strand DNA \\
\hline ssDNA & Single strand DNA \\
\hline ELISA & Enzyme-Linked Immunosorbent Assay \\
\hline FW & Framework region of variable domains \\
\hline $\operatorname{IgH}$ & Immunoglobulin heavy chain \\
\hline IPTG & Isopropyl $\beta$-d-1-thiogalactopyranoside \\
\hline LB & Luria-Bertani broth \\
\hline PBST & Phosphate Buffered Saline added by tween $20(0.5 \% v / v)$ \\
\hline PDB & Protein Data Bank \\
\hline PNPP & $\rho$-Nitro-Phenyl-Phosphate \\
\hline RMSD & Root-Mean-Square Deviation \\
\hline scpre-BCR & Single chain pre-B cell receptor \\
\hline SEC & Size Exclusion Chromatography \\
\hline SLC & Surrogate light chain \\
\hline UR & Highly charged unique regions of the SLC \\
\hline VDW & Van der Waals Interactions \\
\hline $\mathrm{VH}$ & Heavy chain variable domain \\
\hline VL & Light chain variable domain \\
\hline
\end{tabular}




\section{References}

1. Arbuckle, M.R.; James, J.A.; Kohlhase, K.F.; Rubertone, M.V.; Dennis, G.J.; Harley, J.B. Development of Anti-dsDNA Autoantibodies Prior to Clinical Diagnosis of Systemic Lupus Erythematosus. Scand. J. Immunol. 2001, 54, 211-219. [CrossRef]

2. Pianta, A.; Arvikar, S.L.; Strle, K.; Drouin, E.E.; Wang, Q.; Costello, C.E.; Steere, A.C. Two rheumatoid arthritis-Specific autoantigens correlate microbial immunity with autoimmune responses in joints. J. Clin. Investig. 2017, 127, 2946-2956. [CrossRef]

3. Roep, B.O.; Peakman, M. Antigen Targets of Type 1 Diabetes Autoimmunity. Cold Spring Harb. Perspect. Med. 2012,2 , a007781. [CrossRef] [PubMed]

4. Xu, X.; Deobagkar-Lele, M.; Bull, K.R.; Crockford, T.L.; Mead, A.J.; Cribbs, A.P.; Sims, D.; Anzilotti, C.; Cornall, R.J. An ontogenetic switch drives the positive and negative selection of B cells. Proc. Natl. Acad. Sci. USA 2020, 117, 3718-3727. [CrossRef] [PubMed]

5. Rice, J.S.; Newman, J.; Wang, C.; Michael, D.J.; Diamond, B. Receptor editing in peripheral B cell tolerance. Proc. Natl. Acad. Sci. USA 2005, 102, 1608-1613. [CrossRef] [PubMed]

6. Smith, M.J.; Ford, B.R.; Rihanek, M.; Coleman, B.M.; Getahun, A.; Sarapura, V.D.; Gottlieb, P.A.; Cambier, J.C. Elevated PTEN expression maintains anergy in human B cells and reveals unexpectedly high repertoire autoreactivity. JCI Insight $2019,4,4$. [CrossRef] [PubMed]

7. Wardemann, H.; Yurasov, S.; Schaefer, A.; Young, J.W.; Meffre, E.; Nussenzweig, M.C. Predominant Autoantibody Production by Early Human B Cell Precursors. Science 2003, 301, 1374-1377. [CrossRef] [PubMed]

8. Lecerf, J.M.; Chen, Y.; Richalet-Sécordel, P.; Wang, X.; Stollar, B.D. Autoreactivity of human VH domains from cDNA libraries: Analysis with a bacterial expression system. J. Immunol. 1998, 161, 1274-1283.

9. Wang, L.D.; Clark, M.R. B-cell antigen-receptor signalling in lymphocyte development. Immunology 2003, 110, 411-420. [CrossRef]

10. Kenny, E.F.; Raupach, B.; Abu Abed, U.; Brinkmann, V.; Zychlinsky, A. Dnase1-deficient mice spontaneously develop a systemic lupus erythematosus-like disease. Eur. J. Immunol. 2019, 49, 590-599. [CrossRef]

11. Ehlich, A. Immunoglobulin heavy and light chain genes rearrange independently at early stages of B cell development. Cell 1993, 72, 695-704. [CrossRef]

12. Gauthier, L.; Rossi, B.; Roux, F.; Termine, E.; Schiff, C. Galectin-1 is a stromal cell ligand of the pre-B cell receptor (BCR) implicated in synapse formation between pre-B and stromal cells and in pre-BCR triggering. Proc. Natl. Acad. Sci. USA 2002, 99, 13014-13019. [CrossRef] [PubMed]

13. Rossi, B.; Espeli, M.; Schiff, C.; Gauthier, L. Clustering of Pre-B Cell Integrins Induces Galectin-1-Dependent Pre-B Cell Receptor Relocalization and Activation. J. Immunol. 2006, 177, 796-803. [CrossRef] [PubMed]

14. Knoll, M.; Yanagisawa, Y.; Simmons, S.; Engels, N.; Wienands, J.; Melchers, F.; Ohnishi, K. The Non-Ig Parts of the VpreB and $\lambda 5$ Proteins of the Surrogate Light Chain Play Opposite Roles in the Surface Representation of the Precursor B Cell Receptor. J. Immunol. 2012, 188, 6010-6017. [CrossRef] [PubMed]

15. Löffert, D.; Ehlich, A.; Müller, W.; Rajewsky, K. Surrogate Light Chain Expression Is Required to Establish Immunoglobulin Heavy Chain Allelic Exclusion during Early B Cell Development. Immunity 1996, 4, 133-144. [CrossRef]

16. Galler, G.R.; Mundt, C.; Parker, M.J.; Pelanda, R.; Martensson, I.-L.; Winkler, T.H. Surface $\mu$ Heavy Chain Signals Down-Regulation of the V(D)J-Recombinase Machinery in the Absence of Surrogate Light Chain Components. J. Exp. Med. 2004, 199, 1523-1532. [CrossRef]

17. Sun, L.; Kono, N.; Shimizu, T.; Toh, H.; Xue, H.; Numata, O.; Ato, M.; Itamura, S.; Ohnishi, K. Distorted antibody repertoire developed in the absence of pre-B cell receptor formation. Biochem. Biophys. Res. Commun. 2018, 495, 1411-1417. [CrossRef]

18. Boothby, M.R.; Hodges, E.; Thomas, J.W. Molecular regulation of peripheral B cells and their progeny in immunity. Genes Dev. 2019, 33, 26-48. [CrossRef]

19. Mouquet, H.; Nussenzweig, M.C. Polyreactive antibodies in adaptive immune responses to viruses. Cell. Mol. Life Sci. 2011, 69, 1435-1445. [CrossRef]

20. Mi, Q.-S.; Zhou, L.; Schulze, D.H.; Fischer, R.T.; Lustig, A.; Rezanka, L.J.; Donovan, D.M.; Longo, D.L.; Kenny, J.J. Highly reduced protection against Streptococcus pneumoniae after deletion of a single heavy chain gene in mouse. Proc. Natl. Acad. Sci. USA 2000, 97, 6031-6036. [CrossRef]

21. Maranhão, A.Q.; Costa, M.B.W.; Guedes, L.; Moraes-Vieira, P.M.; Raiol, T.; Brigido, M.M. A Mouse Variable Gene Fragment Binds to DNA Independently of the BCR Context: A Possible Role for Immature B-Cell Repertoire Establishment. PLoS ONE 2013, 8 , e72625. [CrossRef] [PubMed]

22. Morstadt, L.; Bohm, A.; Yüksel, D.; Kumar, K.; Stollar, B.D.; Baleja, J.D. Engineering and characterization of a single chain surrogate light chain variable domain. Protein Sci. 2008, 17, 458-465. [CrossRef]

23. Williams, C.J.; Headd, J.J.; Moriarty, N.W.; Prisant, M.G.; Videau, L.L.; Deis, L.N.; Verma, V.; Keedy, D.A.; Hintze, B.J.; Chen, V.B.; et al. MolProbity: More and better reference data for improved all-atom structure validation. Protein Sci. 2018, 27, 293-315. [CrossRef] [PubMed]

24. Herron, J.N.; He, X.M.; Ballard, D.W.; Blier, P.R.; Pace, P.E.; Bothwell, A.L.M.; Voss, E.W.; Edmundson, A.B. An autoantibody to single-stranded DNA: Comparison of the three-dimensional structures of the unliganded fab and a deoxynucleotide-fab complex. Proteins Struct. Funct. Bioinform. 1991, 11, 159-175. [CrossRef] [PubMed]

25. Haji-Ghassemi, O.; Müller-Loennies, S.; Rodriguez, T.; Brade, L.; Kosma, P.; Brade, H.; Evans, S.V. Structural Basis for Antibody Recognition of Lipid A. J. Biol. Chem. 2015, 290, 19629-19640. [CrossRef] [PubMed] 
26. Seidl, K.J.; Wilshire, J.A.; MacKenzie, J.D.; Kantor, A.B.; Herzenberg, L.A. Predominant VH genes expressed in innate antibodies are associated with distinctive antigen-binding sites. Proc. Natl. Acad. Sci. USA 1999, 96, 2262-2267. [CrossRef]

27. Xu, J.L.; Davis, M.M. Diversity in the CDR3 Region of VH Is Sufficient for Most Antibody Specificities. Immunity 2000, 13, 37-45. [CrossRef]

28. Wang, H.; Wang, F.; Wang, W.; Yao, X.; Hengwei, W.; Cheng, H.; Deng, Z. Improving the Expression of Recombinant Proteins in E. coli BL21 (DE3) under Acetate Stress: An Alkaline pH Shift Approach. PLoS ONE 2014, 9, e112777. [CrossRef]

29. Xu, L.; Yee, H.; Chan, C.; Kashyap, A.K.; Horowitz, L.; Horowitz, M.; Bhatt, R.R.; Lerner, R.A. Combinatorial surrobody libraries. Proc. Natl. Acad. Sci. USA 2008, 105, 10756-10761. [CrossRef]

30. Radic, M.Z.; Erikson, J.; Litwin, S.; Weigert, M. B lymphocytes may escape tolerance by revising their antigen receptors. J. Exp. Med. 1993, 177, 1165-1173. [CrossRef]

31. Radic, M.Z.; Seal, S.N. Selection of Recurrent V Genes and Somatic Mutations in Autoantibodies to DNA. Methods 1997, 11, 20-26. [CrossRef]

32. Radic, M.Z.; Weigert, M. Origins of Anti-DNA Antibodies and Their Implications for B-Cell Tolerancea. Ann. N. Y. Acad. Sci. 2008, 764, 384-396. [CrossRef] [PubMed]

33. Yusufaly, T.I.; Li, Y.; Singh, G.; Olson, W.K. Arginine-phosphate salt bridges between histones and DNA: Intermolecular actuators that control nucleosome architecture. J. Chem. Phys. 2014, 141, 165102. [CrossRef] [PubMed]

34. Jackson, S.N.; Wang, H.-Y.J.; Woods, A.S. Study of the Fragmentation Patterns of the Phosphate-Arginine Noncovalent Bond. J. Proteome Res. 2005, 4, 2360-2363. [CrossRef] [PubMed]

35. Pewzner-Jung, Y.; Simon, T.; Eilat, D. Structural elements controlling anti-DNA antibody affinity and their relationship to anti-phosphorylcholine activity. J. Immunol. 1996, 156, 3065-3073.

36. Kalinina, O.; Wang, Y.; Sia, K.; Radic, M.; Cazenave, P.-A.; Weigert, M. Light chain editors of anti-DNA receptors in human B cells. J. Exp. Med. 2014, 211, 357-364. [CrossRef] [PubMed]

37. Oppezzo, P.; Dumas, G.; Bouvet, J.-P.; Robello, C.; Cayota, A.; Pizarro, J.C.; Dighiero, G.; Pritsch, O. Somatic mutations can lead to a loss of superantigenic and polyreactive binding. Eur. J. Immunol. 2004, 34, 1423-1432. [CrossRef]

38. Ferry, H.; Crockford, T.L.; Leung, J.C.H.; Cornall, R.J. Signals from a Self-Antigen Induce Positive Selection in Early B Cell Ontogeny but Are Tolerogenic in Adults. J. Immunol. 2006, 176, 7402-7411. [CrossRef]

39. Zikherman, J.; Parameswaran, R.; Weiss, A. Endogenous antigen tunes the responsiveness of naive B cells but not T cells. Nat. Cell Biol. 2012, 489, 160-164. [CrossRef]

40. Kim, J.-W.; Kwok, S.-K.; Choe, J.-Y.; Park, S.-H. Recent Advances in Our Understanding of the Link between the Intestinal Microbiota and Systemic Lupus Erythematosus. Int. J. Mol. Sci. 2019, 20, 4871. [CrossRef]

41. Watanabe, A.; Su, K.-Y.; Kuraoka, M.; Yang, G.; Reynolds, A.E.; Schmidt, A.G.; Harrison, S.C.; Haynes, B.F.; Clair, E.W.S.; Kelsoe, G. Self-tolerance curtails the B cell repertoire to microbial epitopes. JCI Insight 2019, 4, 4. [CrossRef]

42. Rice, P.; Longden, I.; Bleasby, A. EMBOSS: The European Molecular Biology Open Software Suite. Trends Genet. 2000, 16, $276-277$. [CrossRef]

43. Brigido, M.M.; Polymenis, M.; Stollar, B.D. Role of mouse VH10 and VL gene segments in the specific binding of antibody to Z-DNA, analyzed with recombinant single chain Fv molecules. J. Immunol. 1993, 150, 469-479. [PubMed]

44. Pettersen, E.F.; Goddard, T.D.; Huang, C.C.; Couch, G.S.; Greenblatt, D.M.; Meng, E.C.; Ferrin, T.E. UCSF Chimera-A visualization system for exploratory research and analysis. J. Comput. Chem. 2004, 25, 1605-1612. [CrossRef] [PubMed]

45. Vangone, A.; Spinelli, R.; Scarano, V.; Cavallo, L.; Oliva, R. COCOMAPS: A web application to analyze and visualize contacts at the interface of biomolecular complexes. Bioinformatics 2011, 27, 2915-2916. [CrossRef]

46. Emsley, P.; Lohkamp, B.; Scott, W.G.; Cowtan, K. Features and development of Coot. Acta Crystallogr. Sect. D Biol. Crystallogr. 2010, 66, 486-501. [CrossRef] [PubMed]

47. Webb, B.; Sali, A. Protein Structure Modeling with MODELLER. Methods Mol. Biol. 2014, 1137, 1-15. [CrossRef]

48. Yang, J.; Zhang, Y. I-TASSER server: New development for protein structure and function predictions. Nucleic Acids Res. 2015, 43, W174-W181. [CrossRef] 